\title{
The Association between Risk Disclosure and Firm Characteristics: A Meta-Analysis
}

\begin{abstract}
:
The empirical literature on the determinants of risk disclosures offers mixed results. This complicates efforts among stakeholders to understand the factors affecting firms' decision to report risk information. The aim of our paper is to analyse the findings of 42 empirical studies using a meta-analysis. We examine whether differences in the findings are attributable to random error or due to legal and institutional systems, uncertainty avoidance, the disclosure regime (mandatory versus voluntary), industry types and the proxies of corporate characteristics. We find that all moderators affect the relationship strength between corporate size and risk reporting. Legal system, disclosure regime, industry types and leverage ratio measurement moderate the association between leverage ratio and risk disclosure. Industry types and uncertainty avoidance level affect the relationship between profitability and risk disclosure. Finally, the association between risk factor and risk disclosure is moderated by industry types. We discuss the implications of our findings and offer suggestions for future research.
\end{abstract}

Keywords: Risk reporting, Legal system, Uncertainty avoidance, Disclosure regime, Industry types, Explanatory variables measurement, Meta-analysis. 


\section{The Association between Risk Disclosure and Firm Characteristics: A Meta-Analysis}

\section{Introduction}

Although business risks have always existed, major corporate scandals have led to an increase interest in risk reporting and risk management (Oliveira, Rodriguez and Craig, 2013). Fuller and Jensen (2002: p. 43) argue that "Trying to mask the uncertainty that is inherent in every business is like pushing on a balloon; smoothing out today's bumps means they will only pop up somewhere else tomorrow, often with catastrophic results". Therefore, studying risk disclosure is crucial for the well-functioning of capital markets (Deumes, 2008).

Given this importance, risk disclosure has attracted the interest of several accounting regulators worldwide including The American Accounting Association (AAA), Financial Accounting Standards Board (FASB) and accounting professional bodies (e.g. The Institute of Chartered Accountants in England and Wales (ICAEW)) (Schrand and Elliott, 1998 and Elshandidy et al, 2013). These institutions suggest that there is a risk information gap between firms and shareholders and companies are providing insufficient risk information in their annual reports (Schrand and Elliott, 1998). Therefore, understanding management incentives for risk disclosure represents a relevant information for standard-setters "when they consider how to mandate narrative risk reporting in the non-financial statements of firms' annual reports" (Miihkinen, 2012, p. 3).

Linsely and Shrives (2000) argue that companies become exposed to more volatility and uncertainties. Accordingly, they develop sophisticated ways to identify measure and manage risk. Although these developments, investors know little about firm's risks and risk management and the risk information gap still exist between companies and their stakeholders (Linsley \& Shrives, 2006). Lee (2012) emphasises that companies need 
freedom in reporting their risk information when responding to the stock market requirements. Accordingly, firm's narrative disclosure disclosure may represent an important tool to communicate risk information to investors. Recent research shows variations between companies in reporting risk information (Elshandidy et al., 2013 and Barakat and Hussainey, 2013). (Miihkinen, 2012, p. 1) argues that "it is difficult to evaluate detailed risk guidance in an environment where firms have several disclosure motives". This raises the following important research question: What are the determinants of risk information?

During the last decade, the determinants of risk reporting practices have attracted major interests in accounting and finance literature (Oliveira et al., 2013). However, results reported are mixed. Solomon, Solomon, Norton, and Joseph (2000: 30) suggest that "there has been little attempt by the academic community to summarize developments in risk disclosure". Linsley and Shrives (2006: 400) state that "it would also be beneficial to adopt multi-disciplinary approaches as insights drawn from areas such as sociology may present alternative methodological approaches to assist future risk disclosure research". In this regard, the meta-analysis technique has been widely applied in social sciences (e.g. Theil, 2002; Wåhlberg, 2008) and it is recently used in disclosure literature (e.g. Khlif and Souissi, 2010). Compared to narrative reviews, this technique allows the integration and reconciliation between conflicting findings which leads to more consistent conclusions (Rosenthal, 1991). Therefore, the main objective of this study is to empirically analyse the findings of prior empirical risk disclosure studies using the meta-analysis technique. This should help in achieving a quantitative generalization of these findings which is not possible by a narrative literature review.

Our objective in this study is to advance understanding the determinants of risk disclosure by conducting a meta-analysis of the findings of 42 empirical disclosure studies that 
examine specifically this topic.. We also aim to determine whether the variability of findings across studies is due to differences in different definitions of explanatory variables, or due to differences in research settings (civil versus common law countries and the level of uncertainty avoidance), disclosure regime, type of industries examined and journal quality. The meta-analysis has been widely applied in accounting and finance literature with respect to the determinants of voluntary disclosure literature (e.g., Ahmed and Courtis, 1999; García-Meca and Sánchez-Ballesta, 2010 and Khlif and Souissi, 2010). Our study complements this stream of research by focusing on risk disclosure. Our paper also complements prior syntheses of risk reporting that have taken the form of narrative reviews (e.g. Oliveira et al., 2013). While narrative reviews are important, they might be vulnerable to biased representations of a body of literature and easily lead to false inferences (Drees and Heugens, 2013). Therefore, a quantitative synthesis of the determinants of risk disclosure would help in understanding the factors that affect firms' decision to report risk information

We contribute to disclosure studies by not only presenting an overview discussion on the determinants of risk disclosure, but also by using a meta-analysis of the reported findings on these determinants. Our paper is the first study that applied the meta-analysis which qualitatively combines all the available empirical findings on the impact of firm characteristics on risk disclosure and thus, this technique can be a catalyst for a quantitative generalisation on the factors affecting risk disclosure. The paper also is being the first study to explain the potential reasons for the mixed findings in the risk disclosure literature by identifying the factors that moderate the relationship strength between firm characteristics and risk disclosure.

We find that corporate size, leverage ratio, profitability and risk factors are positively associated with risk reporting. Interestingly, we find that the association between corporate 
size and risk reporting is affected by all moderators. Legal system, disclosure regime, industry types and leverage ratio measurement moderate the association between leverage ratio and risk disclosure. Industry types and uncertainty avoidance level affect the relationship between profitability and risk disclosure. Finally, the association between risk factor and risk disclosure is moderated industry types. Our results emphasise the need to consider legal and institutional characteristics and industry types when one analyses the determinants of risk disclosure.

The next section presents the motives for risk dislcosure. Section 3 reviews the relevant literature and develops the research hypotheses. Section 4 describes data selection. Section 5 presents the research methodology. Section 6 reports the findings. Section 7 concludes.

\section{Risk disclosure definition and motives for risk disclosure}

Risk reporting is defined as a set of information communicated in financial statements dealing with managers' estimates, judgments, reliance on market-based accounting policies such as impairment, derivative hedging, financial instruments, economic, political, financial, management risks and internal control risks (Hassan, 2009; Miihkinen, 2012). This definition is in line with others suggested by several authors (e.g. Schrand and Elliott, 1998) who argue that risk disclosure is all types of information communicated in financial statements dealing with business uncertainties.

Two streams of theories have been employed to explain why firms communicate risk information [Linsley \& Shrives, 2000]. These streams include both the economic theory approach and social and political theory approach (Hassan, 2009; Iatridis, 2008; Oliveira et al. 2013).

The economic theory approach relies on self-interest and profit maximization of economic agents and uses the following frameworks to explain risk disclosure including agency theory, political costs theory, signalling theory, and proprietary costs theory (Hassan, 2009; 
Taylor, Tower and Neilson, 2010), while the social and political approach suggests to understand the motivations of risk disclosure, it is necessary to understand the political and social relationships linking firm to stakeholders in the society (Oliveira et al. 2013). Based on these theories, we will try in the next section to develop hypotheses dealing with the effect of some corporate characteristics and risk disclosure.

\section{Hypotheses development}

Several variables have been used in empirical literature to explain the determinants of risk reporting including corporate characteristics (e.g. size, leverage, risk factor) and corporate governance attributes (e.g. ownership concentration, board independence). To assess the effect of some explanatory variables on voluntary risk reporting, it is necessary to have a sufficiently large number of studies that have empirically addressed a particular variable. Initially we collect information for several variables commonly used in the studies examined including corporate characteristics (size, leverage, profitability and risk factor, multinationality, industry, auditor type) and corporate governance (ownership concentration, board size, board independence). Our choice of corporate size, leverage, profitability and risk factor to meta-analyse the determinants of voluntary risk reporting is mainly influenced by the fact that the number of observations obtained for these variables exceeds at least 19 allowing a reliable statistical analysis and tests for moderating factors.

Several theories have been used to justify the potential impact of corporate size, leverage ratio, corporate profitability and risk factor on voluntary risk reporting. These include agency, proprietary costs, legitimacy and resources-based perspectives theories. In this section, we review studies that have examined the relationship between risk disclosure and the above explanatory variables that have received much attention in financial reporting research over the last decade. We also develop hypotheses with respect to each moderating factor. 


\subsection{Corporate size}

Large firms tend to be more complex and have more varied operations. These characteristic implies higher risk levels which translate into higher information asymmetry among investors (Deumes and Knechel, 2008). According to agency theory, risk reporting may reduce agency costs and information asymmetry between managers and shareholders (Watts and Zimmerman, 1983). In addition, large firms are generally characterised by greater levels of public visibility implying higher public scrutiny among stakeholders (Amran et al., 2009). According to legitimacy theory, the disclosure of risk information will help stakeholders in the evaluation of potential litigation risks and potential reputation damages. This implies that firm has a legitimating process to preserve corporate reputation, reduce corporate risk and signal its legitimacy (Oliveira et al., 2011). Finally, large firms may enjoy economies of scale in developing, implementing, and reporting information regarding market, management and internal control risks since they have more resources to afford disclosure production costs comparative to smaller ones (Deumes and Knechel, 2008; Lopes and Rodrigues, 2007).

The empirical evidence on the effect corporate size on voluntary risk reporting is mixed. While there are research findings showing a negative association between firm size and risk reporting (e.g., Lajili and Zegal, (2005 and Hill and Short. 2009), other research findings show a significant positive association between firm size and risk reporting (e.g., Linsley and Shrives, 2006, Abraham and Cox, 2007, Deumes and Knechel, 2008, Barakat and Hussainey, 2013, Elshandidy et al, 2013, Ntim et al, 2013). . Other studies find no association between both variables (e.g. Doyle, Ge and McVay, 2007; Ashbaugh-Skaife, Collins, William and Kinney Jr, 2007). Given these mixed evidences, the following nondirectional hypothesis is formulated:

Hol: there is an association between corporate size and voluntary risk reporting. 


\subsection{Leverage}

Firms characterised by high leverage ratio tend to be more risky and speculative (Oliveira et al. 2011). Agency theory suggests that agency costs increase with high leverage ratio (Elzahar and Hussainey, 2012). Debtholders of highly leveraged firms may introduce more restrictive covenants into debt contract which will increase agency and monitoring costs. Risk disclosure made by management concerning market, credit and internal control risk may play a critical role in mitigating creditors' concerns about the solvency of their firm and its capabilities to generate enough cash flows in the future (Rajab and Handley-Schachler, 2009). Signalling theory posits also that managers voluntarily disclose risk information when they have a high leverage ratio to signal to investors and creditors the firms' abilities to meet short term and long term commitments (Elzahar and Hussainey, 2012).

Empirical evidence on the relationship between leverage ratio and voluntary risk reporting is inconclusive. While there are research findings showing a positive relationship between leverage and risk disclosure (e.g., Abraham and Cox, 2007, Deumes and Knechel, 2008, Itardis, 2008), other research papers did not find significant association between the two variables (Elzahar and Hussainey, 2012, Ntim et al. 2013, Miihkinen, 2012). Given these mixed evidence, the following non-directional hypothesis is formulated:

Ho2: there is an association between leverage ratio and voluntary risk reporting.

\subsection{Profitability}

Signalling theory is useful for describing managers' behaviour for revealing information to the stock market in order to avoid any undervaluation of their shares (Giner, 1997). Elshandidy et al (2013) argue that high-profitability firms have greater incentives to signal the quality of their performance and their ability to manage risks successfully. Risk disclosure may reduce uncertainty regarding future cash-flows and economic environment which will have a positive effect on firm's shares. In addition, managers are inclined to 
communicate risk-related information to improve the corporation's image and inform stakeholders to signal their managerial skills in managing risks (Iatridis, 2008). Moreover, communicating risk information may reduce information asymmetry between managers and shareholders implying less agency costs. By contrast, Skinner (1994) suggests that bad performance increases managers' incentives to disclosure risk-related information to ensure investors about firm's future prospects and avoid the adverse effect of litigation risks.

With respect to internal control weaknesses reporting, Deumes and Knechel (2008) suggest that profitable firms may have more resources to communicate such type of information. However, given the good financial performance realised by firm, shareholders will underestimate inherent risk and thus neglect such type of disclosure implying less incentives from management to increase internal control risk reporting.

Empirical evidence on the relationship between profitability and voluntary risk reporting is also inconclusive. While Mohobbot (2005) and Miihkinen (2012) find a positive relationship between profitability and risk disclosure Lajili and Zegal (2005) and Oliveira et al.(2011) find a negative association between the two variables.

Given these mixed evidences, we formulate the following non-directional hypothesis:

H03: there is an association between profitability and voluntary risk reporting.

\subsection{Risk factor}

Systematic risk, as measured by the beta or the risk of bankruptcy could also be an important variable to explain risk-related disclosure. Agency theory suggests that managers may publish risk information in order to reduce information asymmetry between insiders and outsiders and hence reducing information asymmetry (Elshandidy et al, 2013). In addition, signalling theory suggests that corporate managers may signal their quality and ability in identifying, measuring and managing risk through reporting more information 
voluntarily. Thus they can distinguish themselves from other managers who may be perceived to manage risk less effectively (Elshandidy et al, 2013).

Company with high risk levels will try to increase risk disclosure to reduce uncertainties among investors implying a better evaluation of risk by market (Hassan, 2009). Disclosing risk-related information in unfavourable situation may also ensure investors about firm's future prospects (Iatridis, 2008). Finally, managers have incentives to communicate riskrelated information and how these risks are managed to signal to a wider range of stakeholders their managerial skills and promote their images in labour market which may translate accordingly in higher compensations (Abraham and Cox, 2007).

Empirical evidence on the relationship between risk factor and voluntary risk reporting is also inconclusive. While Deumes (2008), Miihkinen (2012), Ntim et al. (2013) and Elshandidy et al (2013) find a positive association between risk levels and risk reporting, Lajili and Zegal (2005), Dobler, Lajili, and Zéghal (2011) and Linsley and Shrives (2006) did not find any significant association between the two variables.

Given these mixed evidences, the following non-directional hypothesis is formulated: H04: there is an association between risk factor and voluntary risk reporting.

\subsection{Potential moderators of the risk reporting-firm characteristics associations ${ }^{1}$}

Legal system: Ahmed and Courtis (1999, p. 36) use Meta andlysis to empirically examine the determinants of voluntary disclosure. They argue that 'these inconclusive results could be due to differences in socio economic and political environments between countries'.

\footnotetext{
${ }^{1}$ In risk disclosure literature, three main proxies are used to measure the extent of voluntary risk disclosure including sentences and words count (Amran, Bin, Hassan, 2009), disclosure index (Lajili and Zegal, 2005; Mohobbot, 2005; Linsleya and Shrives, 2006;) and a dummy variable proxy for study examining specifically internal control risk disclosure (Doyle, Ge and McVay, 2007). In addition, some studies combine word counts and disclosure index approach. With respect to disclosure type, some studies focus on specific risk disclosure (e.g. internal control), while others consider several types of risk reporting in their analysis (internal control risk, risk management, market risk).
} 
Hence, we consider civil law countries versus common law countries. Common law and civil law countries have different properties of accounting information and accounting system attributes including professionalism and transparency for common law versus statutory control and secrecy for civil law countries which will impact risk-related disclosure and its determinants for these two accounting groups (Stulz and Williamson, 2003). Hooi (2007) posits and finds that the level of secrecy negatively affects risk-related disclosure in banking industry. Since secrecy represents a prevailing characteristic in civil law countries, it is expected that risk disclosure will be lower in these countries. Dobler, Lajili, and Zéghal (2011) suggest also that legal system may also affect disclosure quality and its determinants in common and civil law systems. As an illustrative example, they suggest that risk disclosure will be lower in Germany as compared to the USA. Therefore, it is expected that legal system moderates the relationship risk reporting and corporate characteristics. Thus, we formulate the following hypothesis:

$H_{1}$ : Legal system moderates the relationship between risk reporting and corporate characteristics.

Uncertainty avoidance: Wong (2012) suggests that uncertainty avoidance is the most influential cultural dimensions that may affect risk disclosure. Hope (2003, p. 221) defines uncertainty avoidance as "the degree to which people feel uncomfortable with ambiguity and an uncertain future". According to Wong (2012) companies with low level of uncertainty avoidance are more open to accept criticisms, challenges and competitions. Therefore, they will communicate more risk management information (Wong, 2012). By contrast, companies operating in high uncertainty avoidance environment may be more reluctant to communicate risk information in order to avoid conflicts and reduce uncertainty of competition (Gray,1988; Wong, 2012).

Therefore, managers operating in settings with high uncertainty avoidance are expected to communicate less risk-related information when they have more political visibility, high 
leverage ratio, high risk factor and high profitability to avoid possible conflicts, restrict the uncertainties of competition and preserve security (Gray, 1988). Accordingly, it is expected that uncertainty avoidance affects the relation between risk reporting and corporate characteristics. Thus, we hypothesise that:

$H_{2}$ : Uncertainty avoidance moderates the relationship between risk reporting and corporate characteristics.

Mandatory versus voluntary disclosure: under mandatory regime, a firm has to align with mandatory requirements in term of risk reporting. Thus firms operating under the same mandatory risk reporting requirement will tend to the same disclosure policy. This implies that there will be a low level of variation in mandatory disclosure among firms. Therefore, corporate characteristics will not exert a significant effect on risk reporting under mandatory regime. Under voluntary regime, a company will have more incentives to communicate information concerning risk disclosure especially if it has high political visibility, high financial and systematic risk. Therefore, it is expected that the regime of disclosure will moderate the association between corporate characteristics and risk reporting. Ahmed and Courtis (1999) finds that the disclosure regime (mandatory versus voluntary) moderates the association between disclosure and corporate characteristics. Thus, the following hypothesis is formulated:

H3: Disclosure regime (mandatory versus voluntary) moderates the relationship between risk reporting and corporate characteristics.

Industry: firms operating in the same sector tend to adopt the same reporting strategy to avoid negative appreciation by the market (Lopes and Rodrigues, 2007). This implies that the focus on the same industry will reduce the variation of disclosure across companies leading to less significant association between corporate characteristics and risk reporting. In addition, financial industry is generally considered as highly regulated sector implying lower variation of risk disclosure across firms and thus less significant association is 
expected between corporate characteristics and risk reporting. Finally, examining risk disclosure for both financial and non-financial may introduce a bias in the empirical analysis since financial companies are risk management entities and they are expected to make significantly different types of risk disclosure and need, therefore, to be examined separately (Linsley and Shrives, 2006). Studies dealing with the determinants of risk disclosure can be classified into three industry types: (i) financial, (ii) mixed financial and non-financial and (iii) excluding financial companies. We expect that the type of industry considered in the sample moderates the association between risk reporting and corporate characteristics. Therefore, we formulate the following hypothesis:

H4: Industry types moderate the relationship between risk reporting and corporate characteristics.

Measurement of corporate characteristics: a meta-analytic accounting literature posits that the measurement of explanatory variables may also affect the examined relationship (Ahmed and Courtis, 1999; Khlif and Souissi, 2010). Accordingly, the proxies used to measure corporate characteristics may also moderate the relationship between risk-related disclosure and corporate characteristics. For instance, corporate size is commonly measured by total assets, total sales, turnover and market capitalization. In this sense, market capitalization is more linked to investors' reactions with respect to risk reporting compared to total assets. By contrast, total assets, total sales and turnover measure the strength of firm's competitive position in its environment and barriers to entry for new firms (Mokhtar and Mellett, 2013). Accordingly, firm characterised by high barriers to entry may disclose more risk-related information since it dominates its competitors who cannot earn strong benefits from this kind of information (Mokhtar and Mellett, 2013).

Return on equity (ROE) and leverage to equities (D/S) are more linked to shareholders' power compared to return on assets (ROA) or leverage to total assets (D/A). Finally, beta as a measure of risk is more linked to investors' reactions since it takes into accounts market 
and firm's return variability, while other proxies such as the probability of bankruptcy (Zscore) are linked to corporate financial conditions. Accordingly, we formulate the following hypothesis:

H5: The proxies used to measure corporate characteristics moderate the relationship risk reporting and corporate characteristics.

\section{Studies included in the meta-analysis}

In order to obtain a comprehensive list of relevant studies, we conduct a series of computer searches on AAA journals, Science Direct, EJSEbsco, Blackwell, Springer, Emerald, Inderscience, ABI Inform, and SSRN. We use several keywords to search for relevant articles including "voluntary risk disclosure and corporate characteristics", "risk reporting and corporate characteristics", "the determinants of voluntary risk disclosure", "internal control risk reporting and corporate characteristics", "drivers of risk disclosure" and "economics incentives for risk reporting". The term "risk" is also replaced by "management market risk" to identify the maximum number of studies. We also consult specialized journals of accounting and finance which devote a great interest to voluntary disclosure and firm characteristics attributes especially The Journal of Risk Finance, International Review of Financial Analysis. References in collected studies are also consulted to identify other empirical papers. In order to avoid significant omissions and the arbitrary selection of papers, we base our search on the recent literature review undertaken by Oliveira et al. (2013) who report almost all studies dealing with the determinants risk disclosure. Our search was guided by tables reporting risk-related studies and the explanatory variables reported for each study ${ }^{2}$.

Initially, we search for several corporate characteristics including corporate size, leverage ratio, profitability, risk factor, cross-listing, board independence and ownership concentration. However, three corporate characteristics were discarded including cross-

\footnotetext{
${ }^{2}$ For more details see Oliveira et al. (2013), tables 1, $2 \& 3$, pages 36-44,
} 
listing, board independence and ownership concentration variables given the limited number of studies allowing us to obtain robust meta-analytic findings ${ }^{3}$.

Our searches yielded a total of 42 articles between 2004 and 2014. Among the 42 papers, 25 articles are published in top ranked journals (AAA, Elsevier, Wiley-Blackwell, Springer, Francis \& Taylor), 13 in decent journals (Emerald, Inderscience and Macmillan) and 4 unpublished articles. Therefore, $60 \%$ (25/42) of the studies included in our sample appears in ranked journals which increases accordingly the reliability of statistical inferences in our meta-analysis. Table 1 illustrates the sample selection process.

\section{Insert Table 1 about here}

Table 2 summarizes the results of 42 empirical papers by year of publication, country focus, uncertainty avoidance score, number of observations sampled, reporting years, and effect size measure $(r)$ for each corporate characteristics: corporate size, leverage profitability and risk factor. Three main methodologies are used to proxy for risk disclosure: sentences and words count, dummy variable and disclosure index.

\section{Insert Table 2 about here}

Table 3 illustrates different proxies used for measuring independent variables. Corporate size is commonly measured using market capitalization, total assets, total sales and turnover. Leverage ratio and profitability ratio are commonly proxied by debt to total assets (D/A) or debt to total equities (D/S) and return on equity (ROE) and return on total assets (ROA) respectively. Finally, risk factor is commonly measured by beta and other risk indicators including the probability of bankruptcy and a loss dummy variable.

\section{Insert Table 3 about here}

\footnotetext{
${ }^{3}$ For these three variables we obtain less than 13 observations.
} 


\section{Methodology}

\subsection{Effect size}

As explained earlier, we use meta-analysis to analyse relevant studies that examined the association between corporate characteristics and risk reporting and evaluate whether the level of association is consistent across the studies and if not, to further explore possible reasons for such conflicting results. Meta-analysis is a statistical technique for summarizing and reviewing previous quantitative empirical literature. By using meta-analysis, a wide range of research topics can be investigated, provided a large body of empirical research exists. It is generally used to overcome the limitations of narrative reviews and increase the limited statistical power of studies with small sample sizes. Furthermore, narrative reviews lack acceptable rules of inference to go from the findings of studies to overall generalizations about the research literature and they are not well-suited to testing for moderating effects. In this regard, a meta-analysis may be a statistical tool which can enable researchers to summarise, in a statistically systematic manner, a large set of empirical results, reconcile conflicting findings and make sense of the rapidly expanding empirical literature (Glass, 1976; Hunter and Schmidt, 1990, Rosenthal, 1991).

The meta-analysis technique requires the computation of the effect size to measure the magnitude of the association between the dependent variable (risk disclosure) and the explanatory variables. The effect size provides information about how much change is evident across all the studies and the magnitude of the association between the dependent variable (risk reporting) and the independent variables, including corporate size, leverage ratio, profitability ratio and risk factor. 
In computing the effect size from the reported statistics, different procedures are used. When a study reports Person's $r$ coefficient, such a statistic is used to calculate the effect size between the disclosure score and the explanatory variable. Whenever other statistics are reported, such as Student $t$ and $Z$ value, the following formulas are used to compute the effect size respectively $\sqrt{\frac{t^{2}}{\left(t^{2}+d f\right)}}$ where $d f$ is the degree of freedom and $\frac{Z}{\sqrt{N}}$.

A meta-analytic database should be analyzed using the following three steps suggested by Hunter and Schmidt (2000):

(i) First, the mean correlation $(\bar{r})$ is calculated as:

$$
\bar{r}=\frac{\sum\left(r_{i} \cdot N_{i}\right)}{\sum N_{i}}
$$

Where $N_{i}$ : Sample size for study i,

$r_{i}$ : Pearson correlation coefficient for study $i$.

(ii) Second, the observed variance $\left(S_{r}^{2}\right)$ and the sampling error variance $\left(S_{e}^{2}\right)$ are calculated using the following formulas:

$$
\begin{aligned}
& S_{r}^{2}=\frac{\sum N_{i}\left(r_{i}-\bar{r}\right)^{2}}{\sum N_{i}}(2) \\
& S_{e}^{2}=\frac{\left(1-\bar{r}^{2}\right)^{2} K}{\sum N_{i}}
\end{aligned}
$$

where $K$ is the number of individual studies included in the meta-analysis.

(iii) Third, the variance used to estimate a confidence interval is $\left(S_{r}^{2} / K\right)$. 
The estimates of population mean $(\bar{r})$ and the standard deviation $\sqrt{S_{r}^{2} / K}$ are normally used to construct a 95 per cent confidence interval and assess the validity of the association of interests as per equation (4):

$$
\left[\bar{r}-\left(\sqrt{S_{r}^{2} / K}\right) Z_{0.975} ; \bar{r}+\left(\sqrt{S_{r}^{2} / K}\right) Z_{0.975}\right]=\left[\bar{r}-\left(\sqrt{S_{r}^{2} / K}\right)(1.96) ; \bar{r}+\left(\sqrt{S_{r}^{2} / K}\right)(1.96)\right]
$$

A 95 percent confidence interval that does not include zero is an indicator that there is a true association between the variables of interest (Dalton, Daily, Johnson and Ellstrand, 1999). Similarly, the following Z-statistic $\left(Z=\frac{\bar{r}}{\sqrt{S_{r}^{2} / K}}\right)$ is computed to assess the significance of the examined relationship. If the computed Z-statistic is significant at $5 \%$ this represents also an indicator of the true relationship between the variables of interest.

In order to test for moderating variables and determine whether the observed variance is trivial or higher than expected, a chi-square statistic test is suggested to assess whether the observed variance is due to moderating effects or to some statistical errors.

$$
\chi_{K-1}^{2}=\frac{N S_{r}^{2}}{\left(1-\bar{r}^{2}\right)^{2}}
$$

If the computed chi-square statistic is trivial compared to the tabulated one, the association is considered unmoderated and homogeneous, and the variation across studies is due only to some statistical (random) errors. Nevertheless, if the computed chi-square statistic is significant, further analyses are conducted to test for moderators and reduce heterogeneity across studies by sub-grouping the sample according to data characteristics (moderators) and study features.

\subsection{Moderating factors}


As mentioned in sub-section (3.5) five moderating factors are examined in the analysis including legal system, the level of uncertainty avoidance, disclosure regimes, industry types and proxies used to measure explanatory variables.

With respect to legal system, Australia, Canada, Malaysia, Malawi, South Africa, USA, UK, Nigeria are classified ${ }^{4}$ as common law countries, while Belgium, Egypt, Finland, Germany, Italy, Japan, Kuwait, Portugal, Netherlands, South Korea, Tunisia, Switzerland, UAE are classified in civil law countries. With regard to uncertainty avoidance, the score for each country is obtained from the following website (http://geerthofstede.com/countries.html). High (low) uncertainty avoidance countries are those which have an uncertainty avoidance score superior (inferior) to the median of our sample.

Concerning disclosure regime, studies are classified into two groups: voluntary disclosure and mandatory regime. Regarding the type of industry, we distinguish between samples dealing only with financial companies (Fin), samples including both financial and nonfinancial companies (mixed) and samples excluding financial companies (Ex-Fin).

With respect to the measurement of explanatory variables, corporate size is commonly measured using market capitalization, total assets, total sales and turnover. Leverage ratio and profitability ratio are commonly proxied by debt to total assets (D/A) or debt to total equities (D/S) and return on equity (ROE) and return on total assets (ROA) respectively. Finally, risk factor is commonly measured by beta, standard deviation of operating return and other risk indicators including the probability of bankruptcy and a loss dummy variable.

\section{Empirical results and discussions}

The results of this study are summarised in tables 4 and 5. In each table, we first present the overall results of the overall meta-analysis, and if the homogeneity test is rejected, we

\footnotetext{
${ }^{4}$ This classification is based on Stulz and Williamson (2003) table 1 pages 323 - 324. Countries like Iran, Tunisia, Malawi and UAE are not listed in this table. For Tunisia, Kuwait and UAE, additional investigations show that they are classified as civil law countries, while Malawi is classified as common law setting. For Iran, no relevant information is found and thus it is dropped from the analysis for this moderator.
} 
conduct further analyses according to legal system, the level of uncertainty avoidance, disclosure regime, industry types and proxies used to measure explanatory variables.

\subsection{Corporate size}

The relationship between corporate size and risk reporting in 43 studies is shown in table (4.A). Overall, consistent with agency theory, the meta-analysis shows that corporate size has a significant positive effect on risk disclosure, with a mean correlation $(\bar{r})$ of $0.075(\mathrm{Z}=$ 2.615) and a 95 per cent confidence interval ranging from 0.018 to 0.132 . Therefore, we accept the hypothesis $\mathrm{H}_{01}$ and conclude that there is a significant positive association between corporate size and risk-related disclosure. These results provide support for agency, political costs and legitimacy theories.

The calculated observed variance $\left(S_{r}^{2}\right)$ shows a high degree of variation (heterogeneity) across the $43^{5}$ studies since the sampling error variance explains only $4.480 \%$ of the observed variance and the computed Chi-square accounts for 959.758 and it is highly significant compared to the tabulated Chi-square at $5 \%$ significance level which amounts $58.124^{6}$. Since heterogeneity is significantly high and explanatory power of the observed variance is low, a sub-group meta-analysis is conducted to reduce heterogeneity by studying five moderator variables as explained earlier.

When sub-group meta-analysis is conducted with respect to legal system, results show that corporate size has a significant positive effect on risk reporting only for civil law countries with a mean correlation of $0.125(\mathrm{Z}=3.113)$ and a confidence interval between 0.046 and 0.203. By contrast, the relationship is non-significant for common law countries with a nearzero mean correlation of $0.027(Z=0.796)$ and high degree of heterogeneity since the sampling error variance explains only $4.790 \%$ of the observed variance and a high computed Chi-square of 417.284. Therefore, $\mathrm{H}_{1}$ is supported and legal system moderates the

\footnotetext{
${ }^{5}$ Since Dobler et al. (2011) encompasses four independent samples.

${ }^{6}$ The tabulated Chi-square statistic with a degree of freedom of 42 (43-1).
} 
relationship between corporate size and risk reporting. This result can be explained by the developed risk reporting practices in common law countries implying lower variation of risk reporting across firms in these settings. In addition, the degree of regulation of risk reporting in common law countries (e.g. the reporting of internal control risk mandated by the SOX act in 2002) may mitigate the association between corporate size and risk reporting in common law countries since companies may adopt the same disclosure policy which reduces the effect of corporate size on risk reporting.

Similarly, uncertainty avoidance moderates also the relationship between corporate size and risk reporting. For instance, the association is only significant for high uncertainty avoidance countries with a mean correlation of $0.146(Z=3.225)$, while it is non-significant for low uncertainty avoidance countries with a mean correlation of $0.005(Z=0.214)$. This implies that corporate size leads to more risk-related disclosure in high uncertainty avoidance settings. Thus $\mathrm{H}_{2}$ is supported. This result is not in line with our expectation. However, in low uncertainty avoidance settings, risk reporting practices are more developed, especially in UK and USA, and this will mitigate the association between corporate size and risk reporting in these settings.

In addition, disclosure regime moderates also the association between corporate size and risk disclosure. For instance, corporate size has a significant positive effect voluntary risk reporting $(0.120 ; \mathrm{Z}=3.254)$, while it is not significantly related for mandatory risk disclosure $(-0.016 ; \mathrm{Z}=-0.465)$. Therefore, $\mathrm{H}_{3}$ is confirmed and disclosure regime moderates the association between corporate size and risk reporting. Under voluntary regime, managers will have more incentives to communicate risk information to distinguish their firm from others. By contrast, mandatory regime will reduce the economic incentives to communicate more risk information since firms have to align with legal requirement and mandatory disclosure practices adopted by other companies. 
When we examine the moderating effect of industry and sample composition, our findings show that the association is significant for financial companies $(0.476 ; Z=4.575)$ and samples excluding non-financial firms $(0.123 ; \mathrm{Z}=3.396)$, while it is non-significant for samples combining financial and non-financial companies $(-0.037 ; Z=-1.429)$. Therefore, $\mathrm{H}_{4}$ is confirmed and industry type moderates the association between corporate size and risk reporting.

Finally, we examine the moderating effect of corporate size measurement ${ }^{7}$; results show that the association is only significant when size is proxied by total assets and total sales with two mean correlations of $0.111(\mathrm{Z}=2.805)$ and $0.242(\mathrm{Z}=2.328)$ respectively. By contrast, the relationship is non-significant for market capitalisation ${ }^{8}$. This result can be explained by the fact that companies with high market capitalisation try to avoid risk disclosure to reduce its adverse effect on firm's value given that investors may interpret this information in different ways. When corporate size is proxied by turnover, the association is also nonsignificant. However, this result has to be interpreted with caution given the limited number of studies used. Based on these meta-analytic findings, we confirm that the association between corporate size and risk disclosure is moderated by explanatory variable proxies and thus $\mathrm{H}_{5}$ is supported. This result confirms that the strength of firm's competitive position in its environment, as proxied by total assets and total sales, increases management incentives to communicate risk information (Mokhtar and Mellett, 2013).

\subsection{Leverage}

\footnotetext{
${ }^{7}$ We note here that the size measures are highly correlated when firms operate in sector with low level of intangibles assets. However, when firms operate in industries where intangible assets account for a large proportion of the assets (e.g. high tech sector), there will be a gap between market capitalisation and total assets. Empirical studies do not control for this factor in their analysis which limits our ability study its moderating effect.

${ }^{8}$ It should be noted here that Souissi and Khlif (2012) have documented in their meta-analysis dealing with the effect of voluntary disclosure on cost of equity capital a non-significant association between cost of equity capital and voluntary disclosure in high disclosure environment including Australia, UK and USA. Given the inverse relationship between cost of equity capital and market capitalisation, and the high weight of Australia, UK and USA for the market capitalisation sub-sample, the same non-significant is expected for market capitalisation and voluntary risk reporting.
} 
Table (4.B) shows the results of the meta-analysis of the association between leverage ratio and risk-related disclosure. Overall, the meta-analysis indicates that leverage ratio is significantly correlated with risk reporting with a mean correlation of $0.067(Z=2.034)$ and a confidence interval between 0.002 and 0.132 . Therefore, $\mathrm{H}_{02}$ is accepted. This finding provides support for agency and signaling theories. Since the homogeneity test is rejected, as indicated by the high value Chi-square statistic (137.584), we undertake further analysis in order to search for moderator variables.

When meta-analytic comparison is conducted according to legal system, findings show that the relationship is non-significant for countries belonging to common law system with a mean correlation of $0.053(Z=1.299)$, while it is significant in civil law countries with a mean correlation of $0.109(\mathrm{Z}=1.993)$. Thus, legal system moderates the relation between risk reporting and leverage ratio and $\mathrm{H}_{1}$ is supported. One plausible explanation for the result is that in civil countries companies operate under bank-oriented system, while companies in common law countries operate under market-oriented system (DemirgüçKunt and Levine, 2001). By contrast, the association between leverage ratio and risk reporting is not moderated by the level of uncertainty avoidance since the association remains insignificant for the high and low uncertainty avoidance groups. Therefore, $\mathrm{H}_{2}$ is not supported.

Sub-group meta-analysis conducted with respect disclosure regime shows that the relationship between leverage ratio and risk disclosure is significant only for voluntary disclosure group with a mean correlation amounting for $0.073(Z=2.150)$, while it is not significant for mandatory disclosure group. Therefore, disclosure regime moderates the association between risk disclosure and leverage and thus $\mathrm{H}_{3}$ is supported. Industry type moderates also the association since the relationship is positive and significant for studies excluding financial companies $(0.082 ; \mathrm{Z}=2.278)$, while it is non-significant for samples 
combining both financial and non-financial firms $(-0.041 ; \mathrm{Z}=-0.534)$. Thus, $\mathrm{H}_{4}$ is also supported.

Finally, we examine the moderating effect of leverage ratio proxy on the association between leverage ratio and risk reporting and we document that the relationship is only significant when the former is measured by debt to total equities (D/S) with a mean correlation of $0.172(\mathrm{Z}=3.556)$, while it is non-significant for $\mathrm{D} / \mathrm{A}$ with a mean correlation of $0.014(\mathrm{Z}=0.551)$. Thus $\mathrm{H}_{5}$ is supported. This result can be explained by the fact that $(\mathrm{D} / \mathrm{S})$ is more linked to shareholders' power and thus high $(\mathrm{D} / \mathrm{S})$ implies more risk related disclosure.

\section{Insert Table 4 about here}

\subsection{Profitability}

In Table (5.C), we report the results of the association between profitability ratio and risk disclosure. The relationship between both variables has a mean correlation of $0.044(\mathrm{Z}=$ 2.006 ), with a 95 per cent confidence interval between 0.001 and 0.088 . Therefore, $\mathrm{H}_{03}$ is supported and the association between risk disclosure and profitability is significant. This result is in line with the predictions of signaling and agency theories. Since only 34 per cent of the observed variance can be explained by sampling error, further tests for moderator variables are undertaken.

When sub-group meta-analysis is undertaken with respect to legal system, findings show that this factor does not moderate the relationship between risk disclosure and profitability. By contrast, when we study the moderating effect of uncertainty avoidance, the association becomes significant only for countries characterized by high uncertainty avoidance with a mean correlation of $0.104(\mathrm{Z}=1.988)^{9}$. For countries characterized by low uncertainty

${ }^{9}$ Countries classified in high uncertainty avoidance group are: Australia, Belgium, Finland, Japan, Kuwait, Portugal, and Switzerland. 
avoidance, the relationship is non-significant with a mean correlation of $0.009(Z=0.585)^{10}$. Thus, $\mathrm{H}_{1}$ is rejected, while $\mathrm{H}_{2}$ is supported and uncertainty avoidance level moderates the association between profitability and risk reporting.

When sub-group meta-analysis is undertaken with respect to disclosure regime, results show that this moderator does not affect the association between profitability and risk reporting. By contrast, industry type moderates the above association since the mean correlation for studies excluding financial companies accounts for $0.056(Z=2.075)$, while it is nonsignificant for studies including financial and non-financial companies $(-0.006 ; Z=-0.151)$. Finally, studies examining only financial companies show a negative and significant relationship between profitability and risk reporting $(-0.040 ; \mathrm{Z}=-10.087)^{11}$. Therefore, $\mathrm{H}_{3}$ is rejected, while $\mathrm{H}_{4}$ is supported.

Finally, we study the moderating effect of profitability measures (ROE versus ROA). Results show that association is a near-zero relationship for ROE with a mean correlation of $0.004(Z=0.452)$, while it is non-significant at $5 \%$ significance level when profitability is proxied by ROA with a mean correlation of $0.053(\mathrm{Z}=1.742)$ with a confidence interval including negative value. Thus, the proxy used to measure profitability does not moderate the association and $\mathrm{H}_{5}$ is rejected.

\subsection{Risk factor}

The results of the meta-analysis of the effect of risk factor on risk disclosure are presented in table (5.D). The analysis of 20 studies shows a significant mean correlation of $0.054(\mathrm{Z}=$ 3.825). Therefore, $\mathrm{H}_{04}$ is supported. The computed Chi-square accounts for (70.147) and it is significant at 1 per cent significance level ${ }^{12}$ and the sampling error variance only explains $28.500 \%$ of the observed variance. Since these two statistics indicate a high degree of

\footnotetext{
${ }^{10}$ Countries classified in high uncertainty avoidance group are: Canada, Netherlands, South Africa, Malawi, UK and USA.

${ }^{11}$ This result should be interpreted with caution given the limited number of studies examined.

${ }^{12}$ The tabulated Chi-square statistic with a degree of freedom of 19 (20-1) accounts for 36.191.
} 
variation (heterogeneity) across the 20 studies, additional tests for moderators are conducted.

When studies are sub-grouped according to legal system, the relationship between risk factor and risk reporting is significant for both civil law settings $(0.043 ; Z=2.064$ and common law countries $(0.053 ; \mathrm{Z}=3.009)$. Similarly, the association is also significant for high and low uncertainty avoidance groups with two mean correlations accounting for 0.065 $(\mathrm{Z}=2.179)$ and $0.045(\mathrm{Z}=3.065)$ respectively. Thus $\mathrm{H}_{1}$ and $\mathrm{H}_{2}$ are not supported.

Sub-group meta-analysis is also undertaken with respect to disclosure regime. Results show that the association is significant for mandatory and voluntary groups with mean correlations accounting for $(0.039: \mathrm{Z}=2.302 ; 0.059: \mathrm{Z}=3.155)$ respectively. By contrast, industry type moderates the association since the relationship between risk factor and risk reporting is significant only for studies that exclude financial companies from their analysis $(0.055 ; Z=3.237)$, while it is non-significant for studies combining financial and nonfinancial firms $(0.048 ; Z=1.643)$ and financial companies $(0.101 ; Z=1.741)$. Therefore, $\mathrm{H}_{3}$ is rejected, while $\mathrm{H}_{4}$ is supported.

Finally, the proxies used to measure risk factor (beta, loss and standard deviation of returns) do not moderate the examined relationship since the mean correlations amount to $(0.091$ ( $\mathrm{Z}$ = 2.989); $0.045(\mathrm{Z}=2.468) ; 0.229$ (6.339)). Therefore, $\mathrm{H} 5$ is not supported.

\section{Insert Table 4 about here}

\subsection{Additional analysis}

Publication quality: Meta-analysis may be affected by the publication bias (Moller and Jennions 2001). Generally, quality journals tend to accept studies with significant results. As 
shown in table (1), 25 papers are published in ranked journals ${ }^{1314}$, while 13 appear in decent journals and 4 are unpublished studies. Therefore, we try to examine whether publication quality affects the examined relationships. The group of quality journals incorporates the 25 papers published in good journals, while the second group includes the 17 remaining papers. The publication quality does not moderate the relationship for leverage ratio and corporate profitability since the association is not significant for low and high quality publications with two mean correlations for leverage ratio that account for $0.039(\mathrm{Z}=1.207)$ and 0.085 $(Z=1.788)$ respectively, and $0.013(Z=0.607)$ and $0.051(Z=1.600)$ respectively for profitability ratio. With respect to risk factor, the association is significant for the two groups $(0.063 ; Z=3.499$ and $0.041 ; Z=3.463)$ respectively for low and high quality journals. Finally, journal quality moderates the association between corporate size and risk reporting since the mean correlation for low quality journals accounts for $0.320(Z=6.951)$, while it is of $0.042(Z=1.386)$ for high quality journals.

File-drawer problem: The above analysis captured the moderating effect for publication status for the sample of the studies included in our meta-analysis. However, it does not account for unpublished studies. Rosenthal (1979) refers to this problem as the 'file drawer problem'. We apply Orwin's (1983) method to determine the extent of the file drawer problem and whether the conclusions drawn from our meta-analysis are likely to be influenced by such publication bias. This method requires the estimation of the fail-safe $\mathrm{N}$ being the number of unreported studies with insignificant results required to reduce the

\footnotetext{
${ }^{13}$ For the purpose of ranking, we used the Association of Business Schools (ABS) list of journals (2010) in order to avoid confusion due to the availability of several university-specific journal rankings. This ranking considers quality journals and classifies them from grade 4 to grade 1 . In our meta-analysis, quality journal are those reported in this raking. All the remaining are considered as decent or low quality journals.

${ }^{14}$ According to ABS, ranked journals are : Accounting and Finance, Auditing: Journal of Practice and Theory, British Accounting Review, Canadian Journal of Administrative Sciences, Journal of Accounting and Economics, Journal of Accounting Research, International Review of Financial Analysis, The International Journal of Accounting, Journal of International Accounting Research, Managerial Auditing Journal, Journal of Financial Regulation and Compliance and The Journal of Risk Finance.
} 
mean effect size to a specified criterion. The fail-safe $\mathrm{N}$ is calculated using equation (6).

$$
K_{0}=K\left[\frac{E S_{k}}{E S_{0}}-1\right] .
$$

$K_{0} \quad$ Fail-safe $\mathrm{N}$ or the number of non significant, unpublished studies

$K \quad$ number of studies included in the meta-analysis

$E S_{k} \quad$ effect size of studies included in the analysis

$E S_{0} \quad$ the criterion effect size of 0.05 significance level which will reduce the effect size to a specified criterion.

The Fail-safe $\mathrm{N}$ is computed when significant relationships are reported. The fail-safe $\mathrm{N}$ ranges from 5 for profitability to 65 for corporate size for overall samples indicating that our results do not suffer from a file drawer problem. Similarly, as show in tables 4 and 5, the fail-safe $\mathrm{N}$ computed for each sub-group that reports significant relationship indicates that the relationship remains stable. For instance, when the association is significant with a limited number of studies (e.g. risk factor as proxied by standard deviation of operating returns), the computed fail-safe $\mathrm{N}$ indicates also the stability of the relationship reported. ${ }^{15}$

\section{Conclusion}

Risk reporting practices have been gaining major interest in accounting literature. More specifically, a large number of disclosure studies have been devoted to studying the effect of corporate characteristics on risk disclosure over the last decade. Accordingly, we apply the meta-analysis technique in the present study in an attempt to summarize and reconcile conflicting findings in the empirical literature and identify possible factors affecting results. Our meta-analysis has investigated the link between risk reporting and four corporate characteristics including corporate size, leverage ratio, profitability and risk factor. The study tests whether the examined relationships are moderated by legal system, level of

\footnotetext{
${ }^{15}$ The fail safe $\mathrm{N}$ accounts for 4 studies.
} 
uncertainty avoidance, disclosure regime, industry types and the proxies used to measure explanatory variables.

Findings show that corporate size, leverage ratio, profitability and risk factor are positively associated with risk reporting. Tests for moderators provide evidence that corporate size and leverage ratio are positively and significantly associated with risk reporting under voluntary disclosure regime. These results provide support for agency, signalling and political costs theories. In addition, corporate size and leverage ratio exert a significant positive effect on risk reporting in civil law countries, while corporate size and profitability are positively associated with risk reporting in high uncertainty avoidance settings. Finally, the association between the four corporate characteristics and risk reporting is non-significant when researchers use samples that include both financial and non-financial companies. This implies that the lack of homogeneity across sectors may introduce a bias into the statistical analysis. Therefore, our findings emphasise the need to explicitly consider the legal and institutional charateritics of one setting and industry type feature when analysing the relationship between corporate characteristics and risk reporting.

By providing a quantitative generalization drawn from a sample of empirical studies dealing with the determinants of risk reporting, our study complements previous meta-analysis conducted in this regard (Ahmed and Courtis, 1999; Khlif and Souissi, 2010) by focusing on specific disclosure topic. In addition, since risk reporting has been the focus of several accounting regulators worldwide including The American Accounting Association (AAA), Financial Accounting Standards Board (FASB) and professional accounting bodies (e.g. ICAEW), understanding why firms communicate risk information is useful for accounting standard-setters to reduce the information risk gap between firms, shareholders and stakeholders. Finally, the present study provides also a foundational knowledge resource with respect to the topic dealing with the determinants of risk disclosure that will inform 
practice and future research initiatives. Accordingly, our meta-analysis provides guidance for future research in under-researched settings helping researchers to identify theoretical frameworks, previous empirical literature and methodologies used.

There are limitations inherent in this study. The computation of effect size from several studies conducted in different contexts, over different periods and using a wide range of econometric methodologies including multiple regression analysis and non-parametric tests, could introduce a bias in the overall results and create 'apples and oranges' problems. However, our analysis is in line with previous meta-analyses conducted in accounting (Ahmed and Courtis, 1999; García-Meca and Sánchez-Ballesta, 2009 and García-Meca and Sánchez-Ballesta, 2010), in Auditing (Trotman and Wood, 1991). In addition, Christie (1990) argues that the computation of effect size from the multiple regression technique does not violate the independence assumption required to conduct statistical analysis. Our meta-analysis does not account for the bad versus good information risk disclosure. However, primary data collected from studies do not allow us to control for the moderating effects of this important aspect in risk reporting. Moreover, studies have employed different composition of risk disclosure indices in terms of number of items, types of risk included and the quantification of disclosure level (e.g. number of sentences, dummy variables). Finally, the inclusion of unpublished studies or studies published in low quality journals may also introduce a bias in the statistical analysis. However, we control for the effect of publication bias in meta-analytic results.

Several avenues for future research exist with respect to the determinants of risk disclosure. First, since there is a limited number of studies dealing with the effect of governance attributes (e.g. ownership concentration, board characteristics), future meta-analysis may examine this topic when a sufficient number of studies are available. In addition, distinguishing between good versus bad news risk disclosures may increase our 
understanding of the determinants and the value relevance of risk disclosure. Furthermore, cross-country studies can be undertaken to examine how cultural dimensions may affect risk disclosure within specific industry sectors. It is, also, interesting that future research focuses on internal control weaknesses disclosure especially in countries where this topic remains under-researched (civil law European countries). Finally, since the association between corporate size and market capitalisation is mixed, future research may examine more comprehensively the economic consequences of risk information especially with respect to cost of equity capital and test its value relevance.. 


\section{References}

* Studies included in the meta-analysis.

* Abraham, S., and Cox, P. 2007. Analysing the determinants of narrative risk information in UK FTSE 100 annual reports. The British Accounting Review 39: 227-248.

* Abdul Rahman, R., Kighir, A., Olabisi, L.. and Abdel Salam, O. 2013. Risk management disclosure practices of Islamic banks in the Mena region: An empirical analysis. MiddleEast Journal of Scientific Research 15 (1): 152-160.

Ahmed, K., and Courtis, JK. 1999. Associations between corporate characteristics and disclosure levels in annual reports: A meta-analysis. The British Accounting Review 31(1): $35-61$.

*Al-Shammari, B. 2014. Kuwait corporate characteristics and level of risk disclosure: a content analysis approach. Journal of Contemporary Issues in Business Research 3(3): 128153.

*Amran, A., Bin, A. M. R., and Hassan, B. C. H. M. 2009. An exploratory study of risk management disclosure in Malaysian annual reports. Managerial Auditing Journal 24(1): $39-57$.

Artiach, T. C., and Clarkson, P. M. 2011. Disclosure, conservatism and the cost of equity capital: A review of the foundation literature. Accounting \& Finance 51: 2-49.

*Ashbaugh-Skaife, H., Collins, D., and Kinney, W. 2007. The discovery and reporting of internal control deficiencies prior to SOX-mandated audits. Journal of Accounting and Economics 44: 166-192.

*Baraket, A., and Hussainey, K. 2013. Bank governance, regulation, supervision, and risk reporting: Evidence from operational risk disclosures in European banks. International Review of Financial Analysis, 30, 254-273.

Beck, T., Demirgüç-Kunt, A., and Levine, R., 2001. The financial structure database. In: Demirgüç-Kunt, A., Levine, R. (Eds.), Financial Structure and Economic Growth: A CrossCountry Comparison of Banks, Markets, and Development. MIT Press, Cambridge, MA, pp. $17-80$

*Beretta, S., and Bozzolan, S. 2004. A framework for the analysis of firm risk communication. The International Journal of Accounting 39: 265-288.

Carlon, S., Loftus, J.A., and Miller, M. 2003. The challenge of risk reporting: regulatory and corporate responses. Australian Accounting Review 13 (3): 36-51.

* Choi, J., Choi, S., Hogan, C., and Lee, J. 2013. The effect of human resource investment in internal control on the disclosure of internal control weaknesses. Auditing: A Journal of Practice \& Theory 32 (4): 169-199.

Christie, A. 1990. Aggregation of test statistics: an evaluation of the evidence on contracting and size hypotheses. Journal of Accounting and Economics 12 (January): 15-36. 
Dalton, D. R., Daily, C. M., Ellstrand, A. E., and Johnson, J. L. 1998. Meta-analytic reviews of board composition, leadership structure, and financial performance. Strategic Management Journal 24: 269-290.

*Deumes, R. 2008. Corporate risk reporting: a content analysis of corporate risk disclosures in prospectuses. Journal of Business Communication 45 (2): 120-157.

*Deumes, R., and Knechel, R. W. 2008. Economic incentives for voluntary reporting on internal risk management and control systems. Auditing: a Journal of Practice \& Theory 27 (1): 35-66.

Dobler, M. 2008. Incentives for risk reporting - a discretionary disclosure and cheap talk approach. International Journal of Accounting: 43(2), 184-206.

*Dobler, M., Lajili, K., and Zéghal, D. 2012. Attributes of corporate risk disclosure: and international investigation in the manufacturing sector. Journal of International Accounting Research 10 (2): 1-22.

*Doyle, J., Ge, W., and McVay, S., 2007. Accruals quality and internal control over financial reporting. The Accounting Review 82: 1141-1170.

*Doyle, J., Weili Ge, W., and McVay, S. 2007. Determinants of weaknesses in internal control over financial reporting. Journal of Accounting and Economics 44:193-223.

Drees, J., and Heugens, P. 2013. Synthesising and extending resource dependence theory: a meta-analysis. Journal of Management 39 (6): 1666-1698.

*Elzahar, H., and Hussainey, K. 2012. Determinants of narrative risk disclosures in UK interim reports. Journal of Risk Finance 13 (2): 133-147.

*Elshandidy, T. 2011. Risk reporting incentives: A cross-country study. Thesis submitted to the Accounting and Finance Division, the University of Stirling.

*Elshandidy, T., Fraser, I., and Hussainey, K. 2013. Aggregated, voluntary, and mandatory risk disclosure incentives: evidence from UK FTSE all-share companies, International Review of financial Analysis, 30, 320-333

Fuller, J., and Jensen, M. 2002. Just say no to Wall Street. Journal of Applied Corporate Finance 14: 41-46.

García-Meca, E., and Sánchez-Ballesta, J.P. 2009. Corporate governance and earnings management: a meta-analysis. Corporate Governance: An International Review 17 (5): 594 -610 .

García-Meca, E., and Sánchez-Ballesta, J. P. 2010. The association of board independence and ownership concentration with voluntary disclosure: a meta-analysis. European Accounting Review 19: 603-627.

Glass, G. 1976. Primary, secondary, and meta-analysis of results. Educational Researcher 5: 3-8. 
*Ge, W., and McVay, S. 2005. The disclosure of material weaknesses in internal control after the Sarbanes-Oxley act. Accounting Horizons 19: 137-158

Gray, S.J. 1988. Towards a theory of cultural influence on the development of accounting systems internationally. Abacus 24 (1): 1-15.

*Hassan, M.K. 2009. UAE corporations-specific characteristics and level of risk disclosure. Managerial Auditing Journal 24 (7): 668-687.

*Hemrit, W., and Ben Arab, M. 2011. The disclosure of operational risk in Tunisian insurance companies. The Journal of Operational Risk 6 (2): 69-111.

*Hill, P., and Short, H. 2009. Risk disclosures on the second tier markets of the London stock exchange. Accounting and Finance 49 (4): 753-780.

Hope, O.-K. 2003. Firm-level disclosures and the relative roles of culture and legal origin. Journal of International Financial Management \& Accounting 14 (3): 218-248.

Hooi, G. 2007. The effects of culture on international banking disclosure. Asia Pacific Journal of Accounting and Economics 14(1): 7-25.

Hunter, J. E., and Schmidt, F. L. 1990. Methods of meta-analysis: Correcting error and bias in research findings. Beverly Hills CA: Sage.

Hunter, J. E., and Schmidt, F. L. 2000. Fixed effects vs. random effects meta-analysis models: Implications for cumulative research knowledge. International Journal of Selection and Assessment 8(4): 275-292.

Hunter, J.E., Schmidt, F. L., and Jackson, G. B. 1982. Cumulating research findings across studies. Studying Organizations: Innovations in Methodology 4 Beverly Hill: Sage.

*Hunzike, S. 2013. The disclosure of market risk information under IFRS 7 Evidence from Swiss listed non-financial companies. Available at:

http://www.hslu.ch/ifz_workingpaper20_the_disclosure_of_market_risk_info_ifrs_7.pdf.

*Iatridis, G. 2008. Accounting disclosure and firms' financial attributes: evidence from the UK stock market. International Review of Financial Analysis 17: 219-241.

Khlif, H., and Souissi, M. 2010. The determinants of corporate disclosure: a meta-analysis. International Journal of Accounting and Information Management 18 (3): 198-219.

*Konishi, N., and Ali, M. 2007. Risk reporting of Japanese companies and its association with corporate characteristics. International Journal of Accounting and Performance Evaluation 4 (3): 263-285. 
Lee, P. 2012. Discussion of 'Risk reporting quality: implications of academic research for financial reporting policy' by Stephen G. Ryan (2012). Accounting and Business Research 42 (3): $325-327$

*Lajili, K., and Zeghal, D. 2005. A content analysis of risk management disclosures in Canadian annual reports. Canadian Journal of Administrative Sciences 22 (2): 125-142.

*Linsley, P., and Shrives, P. 2000. Risk management and reporting risk in the UK, Journal of Risk, 3 (1), 115-129.

Linsley, P., and Shrives, P. 2005. Examining risk reporting in UK public companies. Journal of Risk Finance 6 (4): 292-305.

*Linsley, P., and Shrives, P. 2006. Risk reporting: a study of risk disclosures in the annual reports of UK companies. The British Accounting Review 38 (1): 387-404.

*Linsley, P., Shrives, P.J., and Crumpton, M. 2006. Risk disclosure: An exploratory study of UK Canadian banks. Journal of Banking Regulation 7 (3/4): 268-82.

*Lipunga, A. 2014. Risk disclosure practices of Malawian commercial banks. Journal of Contemporary Issues in Business Research 3 (3): 154-167.

*Lopes, P. T., and Rodrigues, L. L. 2007. Accounting for financial instruments: An analysis of the determinants of disclosure in the Portuguese stock exchange. International Journal of Accounting 42(1): 25-56.

Marshall, A., and Weetman, P. 2002. Information asymmetry in disclosure of foreign exchange risk management: can regulation be effective?. Journal of Economics and Business 54: 31-53.

*Miihkinen, A. 2012. What drives quality of firm risk disclosure? The impact of a national disclosure standard and reporting incentives under IFRS. The International Journal of Accounting 47 (4): 437-468

*Mohobbot, A. 2005. Corporate risk reporting practices in annual reports of Japanese companies. Japanese Journal of Accounting 16 (1), 113-133.

*Mokhtar, E, S., and Mellett, H. 2013.Competition, corporate governance, ownership structure and risk reporting. Managerial Auditing Journal 28 (9): 838-865..

*Nitim, C. G., Lindop, S., and Thomas, D. A. 2013. Corporate governance and risk reporting in South Africa: a study of corporate risk disclosures in the pre- and post2007/2008 global financial crisis period. International Review of Financial Analysis 30: 363-383.

*Oliveira, J.S., Rodrigues, L.L., and Craig, R. 2011b. Voluntary risk reporting to enhance institutional and organizational legitimacy: evidence from Portuguese banks. Journal of Financial Regulation and Compliance 19 (3): 271-288. 
*Oliveira, J.S., Rodrigues, L.L., and Craig, R. 2011c. Risk-related disclosures by nonfinance companies: Portuguese practices and disclosure characteristics. Managerial Auditing Journal 26 (9): 817-839.

Oliveira, J.S., L.L. Rodrigues, and R. Craig. 2013. Risk reporting: a literature review. Working paper Number 1/2013, University of Aveiro, Aveiro, Portugal.

Orwin, R. G. 1983. A fail-safe N for effect size in meta-analysis. Journal of Educational Statistics 8: 157-159.

*Peters, G., and Romi, A. 2012. The Effect of Corporate Governance on Voluntary Risk Disclosures: Evidence from Greenhouse Gas Emission Reporting. Available at: http://www.business.utah.edu/sites/default/files/documents/school-ofaccounting/ghg_disclosure_and_corp_gov_20120202.pdf

Rajab, B., and Handley-Schachler, M. 2009. Corporate risk disclosure by UK firms: trends and determinants. World Review of Entrepreneurship, Management and Sustainable Development 5 (3): 224-243.

Rosenthal, R. 1979. The "file drawer problem" and tolerance for null results. Psychological Bulletin 86 (3): 638-641.

Rosenthal, R. 1991. Meta-Analytic Procedures for Social Research. Applied Social Research Methods Series : 6 Newbury Park: Sage.

*Rice, S. C., and Weber, D. P. 2012. How effective is internal control reporting under SOX 404? Determinants of the (non-) disclosure of existing material weaknesses. Journal of Accounting Research 50 (3): 811-844.

*Savvides, S. C., and Savvidou, N. 2012. Market risk disclosures of banks: a cross-country study. International Journal of Organizational Analysis 20 (4): pp.379 - 405

Schrand, C.M., and Elliott, J.A. 1998. Risk and financial reporting: a summary of the discussion at the 1997 AAA/FASB conference. Accounting Horizons 12 (3): 271-282.

Solomon, J.F., Solomon, A., Norton, S.D., and Joseph, N.L. 2000. A conceptual framework for corporate risk disclosure emerging from the agenda for corporate governance reform. British Accounting Review 32 (4): 447-478.

*Soodanian1, S., Navid, J., and Kheirollahi, F. 2013. The relationship between firm characteristics and internal control weaknesses in the financial reporting environment of companies listed on the Tehran Stock Exchange, Journal of Applied Environmental and Biological Sciences 3(11): 68-74,

Souissi, M., and Khlif, H. 2012. Meta-analytic review of disclosure level and cost of equity capital. International Journal of Accounting and Information Management 20 (1): 49 - 62.

Stulz, R. M., and Williamson, R. 2003. Culture, openness, and finance. Journal of Financial Economics 70: 313-349. 
*Taylor, G., G. Tower, G., Neilson, J. 2010. Corporate communication of financial risk. Accounting and Finance 50 (2): 417-446.

Theil, M. 2002. The role of translations of verbal into numerical probability expressions in risk management: a meta-analysis. Journal of Risk Research 5 (2): 177-186.

Trotman, K., and Wood, R. 1991. A meta-analysis of studies on internal control judgements. Journal of Accounting Research 29 (Spring): 180-192.

*Uba Adamu, M. (2013). Risk reporting: a study of risk disclosures in the annual reports of listed companies in Nigeria. Research Journal of Finance and Accounting 4 (16): 140-147.

*Vandemaele, S., Vergauwen, P., and Michiels, A. 2009. Management risk reporting practices and their determinants: A study of Belgian listed firms. Available at: https://uhdspace.uhasselt.be/dspace/bitstream/1942/9392/2/CorporateriskB.pdf.

Wåhlberg, A. E. 2008. Meta-analysis of the difference in accident risk between long and short truck configurations. Journal of Risk Research. 11 (3): 315-333.

Wong, S. P. 2012. The impact of culture on risk management disclosures: an exploratory study of international banks. DBA thesis, Southern Cross University, Lismore, NSW. 
Table 1. Sample selection

\begin{tabular}{lrr}
\hline & Number of studies & Percentage \\
\hline Initial sample & 52 & $100 \%$ \\
\hline Criteria leading to exclusion of studies & 10 & 19.607 \\
Studies providing only descriptive statistics (a) & 42 & 83.393 \\
Final sample & Number of studies & Percentage \\
\hline Publication quality & 25 & 59.523 \\
& 13 & 30.952 \\
Ranked journals & 4 & 9.525 \\
Decent referred Journals & 42 & $100 \%$ \\
Unpublished studies & & \\
Total & & \\
\hline
\end{tabular}

Notes: (a) Carlon, Loftus, and Miller. (2003); Marshall and Weetman (2002) 
Table 2. Studies included in the meta-analysis

\begin{tabular}{|c|c|c|c|c|c|c|c|c|c|c|c|}
\hline \multirow{2}{*}{ Studies } & \multirow{2}{*}{ Country } & \multirow{2}{*}{$\begin{array}{l}\text { No of } \\
\text { firms }\end{array}$} & \multirow{2}{*}{ Reporting years } & \multirow[t]{2}{*}{ Sector } & \multirow{2}{*}{$\begin{array}{l}\text { Mandatory/ } \\
\text { Voluntary }\end{array}$} & \multirow{2}{*}{$\begin{array}{l}\text { Disclosure } \\
\text { proxy }\end{array}$} & \multicolumn{4}{|c|}{ Effect size (Person's coefficient) } & \multirow{2}{*}{ Sources of information } \\
\hline & & & & & & & Size & Profitability & leverage & Risk & \\
\hline Beretta \& Bozalan (2004) & Italy & 85 & 2001 & EXF & Voluntary & NS & 0.650 & & & & Table. 6, p. 18 \\
\hline Ge and Mac Vay (2005) & USA & 261 & 2002-2004 & Mixed & Mandatory & NS & -0.030 & & -0.040 & & Table. 5, p. 151 \\
\hline Lajili \& Zegal (2005) & Canada & 228 & 1999 & Mixed & Voluntary & DI (72) & -0.086 & -0.046 & 0.029 & 0.013 & Table 2, P. 131 \\
\hline Mohobbot (2005) & Japan & 90 & 2003 & Mixed & Voluntary & DI (58) & 0.261 & 0.102 & 0.065 & & Tables. $4,4,6$, p. $124 \& 125$ \\
\hline Linsleya \& Shrives (2006) & UK & 79 & 2000 & EXF & Voluntary & DI (37) & 0.476 & & 0.139 & 0.053 & Table. 4 , p. 397 \\
\hline Linsleya \& Shrives (2006) & $\begin{array}{l}\text { UK \& } \\
\text { Canada }\end{array}$ & 18 & 2001 & Financial & Mandatory & NS & 0.615 & 0.121 & & -0.194 & Table. 7, p. 279 \\
\hline Abrahama and Cox (2007) & UK & 71 & 2002 & EXF & Voluntary & & 0.232 & & 0.176 & 0.365 & Table. 4, p. 241 \\
\hline Doyle et al. (2007) & USA & 3918 & 2003-2005 & Mixed & Mandatory & DV & -0.035 & & & 0.032 & Table. 7 MW_Company_level, p. 215 \\
\hline Doyle et al. (2007) & USA & 3588 & 2002-2005 & Mixed & Mandatory & DV & -0.053 & & & 0.107 & Table. 3 , p. 1156 \\
\hline Ashbaugh-Skaife et al. (2007) & USA & 4810 & 2003-2004 & EXF & Voluntary & DV & -0.024 & & & 0.039 & Table. 4 (model. 2), p. 182 \\
\hline Konish \& Ali (2007) & Japan & 100 & 2003 & EXF & Voluntary & DI (18) & 0.314 & & & & Table. 5, p. 274 \\
\hline Lopes and Rodriguez (2007) & Portugal & 47 & 2001 & Mixed & Mandatory & DI (54) & 0.249 & & 0.148 & & Table. 9 , p. 45 \\
\hline Deumes (2008) & Netherlands & 31 & 1990 & Mixed & Voluntary & Factor loading & 0.540 & & & 0.570 & Table. 3 (A), p. 141 \\
\hline Deumes \& Knechel (2008) & Netherlands & 490 & 1997-1999 & EXF & Voluntary & DI (6) & 0.530 & -0.030 & 0.200 & & Table. 3 , p. 53 \\
\hline 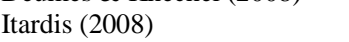 & UK & 215 & 2004 & EXF & Voluntary & DV & 0.079 & 0.124 & 0.138 & & Table, 1 (panel F), p. 229 \\
\hline Amran et al. (2009) & Malyasia & 100 & 2006 & Mixed & Voluntary & NS & 0.617 & 0.086 & & & Table. 5, p. 50 \\
\hline Hassan (2009) & UAE & 41 & 2006 & Mixed & Voluntary & DI (45) & 0.193 & & 0.448 & & Table. 3, p.677 \\
\hline Hill \& Short (2009) & UK & 420 & 1991-1999 & Mixed & Voluntary & DV & -0.109 & & -0.148 & & Tale. 4 B, 774 \\
\hline $\begin{array}{l}\text { Rajab \& Handley-Schachler } \\
\text { (2009) }\end{array}$ & UK & 156 & $\begin{array}{l}1998-2001 \& \\
2004\end{array}$ & EXF & Voluntary & NS & 0.084 & & 0.066 & & Table. 7, p. 12 \\
\hline Vandemaele et al. (2009) & Belguim & 46 & 2006 & EXF & Voluntary & NS & 0.391 & 0.385 & & 0.240 & Table. 6, p. 14 \\
\hline Taylor et al. (2010) & Australia & 424 & $2002-2006$ & EXF & Voluntary & DI (14) & 0.677 & 0.288 & 0.415 & & Table. 3 , p. 430 \\
\hline Dobler et al. 2011 & US & 37 & 2005 & EXF & Mandatory & DI (13) & 0.349 & & 0.448 & 0.031 & Table. 5, (B, C, D, E) p. $16 \& 17$ \\
\hline Dobler et al. 2011 & Canada & 36 & 2005 & EXF & Mandatory & DI (13) & 0.455 & & 0.052 & 0.355 & Table. 5, (B, C, D, E) p. $16 \& 17$ \\
\hline Dobler et al. 2011 & UK & 40 & 2005 & EXF & Mandatory & DI (13) & 0.429 & & 0.061 & -0.049 & Table. 5, (B, C, D, E) p. $16 \& 17$ \\
\hline Dobler et al. 2011 & Germany & 40 & 2005 & EXF & Mandatory & DI (13) & 0.432 & & -0.335 & -0.038 & Table. 5, (B, C, D, E) p. $16 \& 17$ \\
\hline Elshandidy (2011) & $\mathrm{SC}$ & 795 & 2007-2009 & EXF & Voluntary & NS & 0.092 & 0.019 & & 0.082 & Table. 7.7., p. 170 \\
\hline Hemrit \& Ben Arab (2011) & Tunisia & 129 & $2000-2009$ & Financial & Voluntary & DV & 0.220 & 0.055 & 0.229 & & table. 8, p. 102 \\
\hline Oliveira et al. (2011) & Potugal & 111 & 2006 & Financial & Voluntary & DI (24) & 0.510 & -0.080 & & & Table. 5 , p. 282 \\
\hline Oliveira et al. (2011) & Potugal & 81 & 2005 & EXF & Voluntary & NS & 0.390 & & 0.150 & & Table. 5, p. 833 \\
\hline Elzahar \& Hussainey, (2012) & UK & 72 & 2009 & EXF & Voluntary & NS & 0.373 & 0.060 & -0.073 & & Table. 5, p. 142 \\
\hline Miihkinen (2012) & Finland & 198 & 2005-2006 & EXF & Mandatory & DI (41) & 0.235 & 0.152 & -0.168 & 0.185 & Table. 4 , p. 16 \\
\hline Peters \& Romi (2012) & USA & 1238 & $2002-2006$ & EXF & Voluntary & DV & 0.260 & -0.016 & -0.006 & & Table. 7 \\
\hline Rice \& Weber (2012) & USA & 488 & 2004-2009 & Mixed & Mandatory & DV & $-0,088$ & & & 0.162 & Table. 4, p. 829 \\
\hline Savvides \& Savvidou (2012) & $\mathrm{SC}$ & 30 & 2008 & Financial & Voluntary & NS & 0.522 & & & & Table. 4, p. 394 \\
\hline Choi et al. (2013) & South Korea & 5402 & $2005-2008$ & EXF & Mandatory & DV & 0.040 & & & 0.035 & Table. 4 , p. 183 \\
\hline Hunziker (2013) & Swizerland & 67 & 2011 & EXF & Mandatory & NS & 0,437 & 0.158 & 0.368 & -0.03 & Table. 6, p. 14 \\
\hline Baraket \& Husseiny (2013) & $\mathrm{SC}$ & 243 & $2008-2010$ & Financial & Voluntary & DI (40) & 0.709 & & & 0.125 & Table. 2, p. 35 \\
\hline Elshandidy et al. (2013) & UK & 1216 & 2005-2009 & EXF & Voluntary & NS & 0,094 & 0.011 & & & Table. 2 , p. 45 \\
\hline
\end{tabular}

\section{Table 2. Continued}




\begin{tabular}{|c|c|c|c|c|c|c|c|c|c|c|c|}
\hline \multirow{2}{*}{ Studies } & \multirow{2}{*}{ Country } & \multirow{2}{*}{$\begin{array}{l}\text { No of } \\
\text { firms }\end{array}$} & \multirow{2}{*}{ Reporting years } & \multirow[t]{2}{*}{ Sector } & \multirow{2}{*}{$\begin{array}{l}\text { Mandatory/ } \\
\text { Voluntary }\end{array}$} & \multirow{2}{*}{$\begin{array}{l}\text { Disclosure } \\
\text { proxy }\end{array}$} & \multicolumn{4}{|c|}{ Effect size (Person's coefficient) } & \multirow{2}{*}{ Sources of informatior } \\
\hline & & & & & & & $\overline{\text { Size }}$ & Profitability & leverage & Risk & \\
\hline Mokhtar \& Mellett (2013) & Egypt & 72 & 2007 & $\overline{E X F}$ & Voluntary & DI (40) & 0.219 & & & & Table. 4, p. 19 \\
\hline Ntim et al. (2013) & South Africa & 500 & $2002-2011$ & EXF & Voluntary & NS & 0.206 & 0.080 & -0.039 & 0.210 & Table 6. p. 43 \\
\hline Abdul Rahman et al. (2013) & $\mathrm{SC}$ & 60 & $2008-2010$ & Financial & Mandatory & NS & -0.041 & & & & Table. 5, p. 157 \\
\hline Soodanian et al. (2013) & Iran & 174 & 2010 & EXF & Voluntary & DV & -0.028 & & & 0.389 & Table. 5, p. 72 \\
\hline Uba Adamu (2013) & Nigeria & 12 & 2010 & EXF & Voluntary & DI (25) & & & -0.288 & & Table 4.7, p. 145 \\
\hline Al-Shammari (2014) & Kuwait & 109 & 2012 & EXF & Voluntary & NS & 0.259 & -0.053 & 0.062 & & Table. 6, p. 143 \\
\hline Lipunga (2014) & Malawi & 7 & 2012 & Financial & Voluntary & DI (34) & & -0.331 & & & Table. 5, p. 163 \\
\hline
\end{tabular}

Table 3. Proxies for explanatory variables 


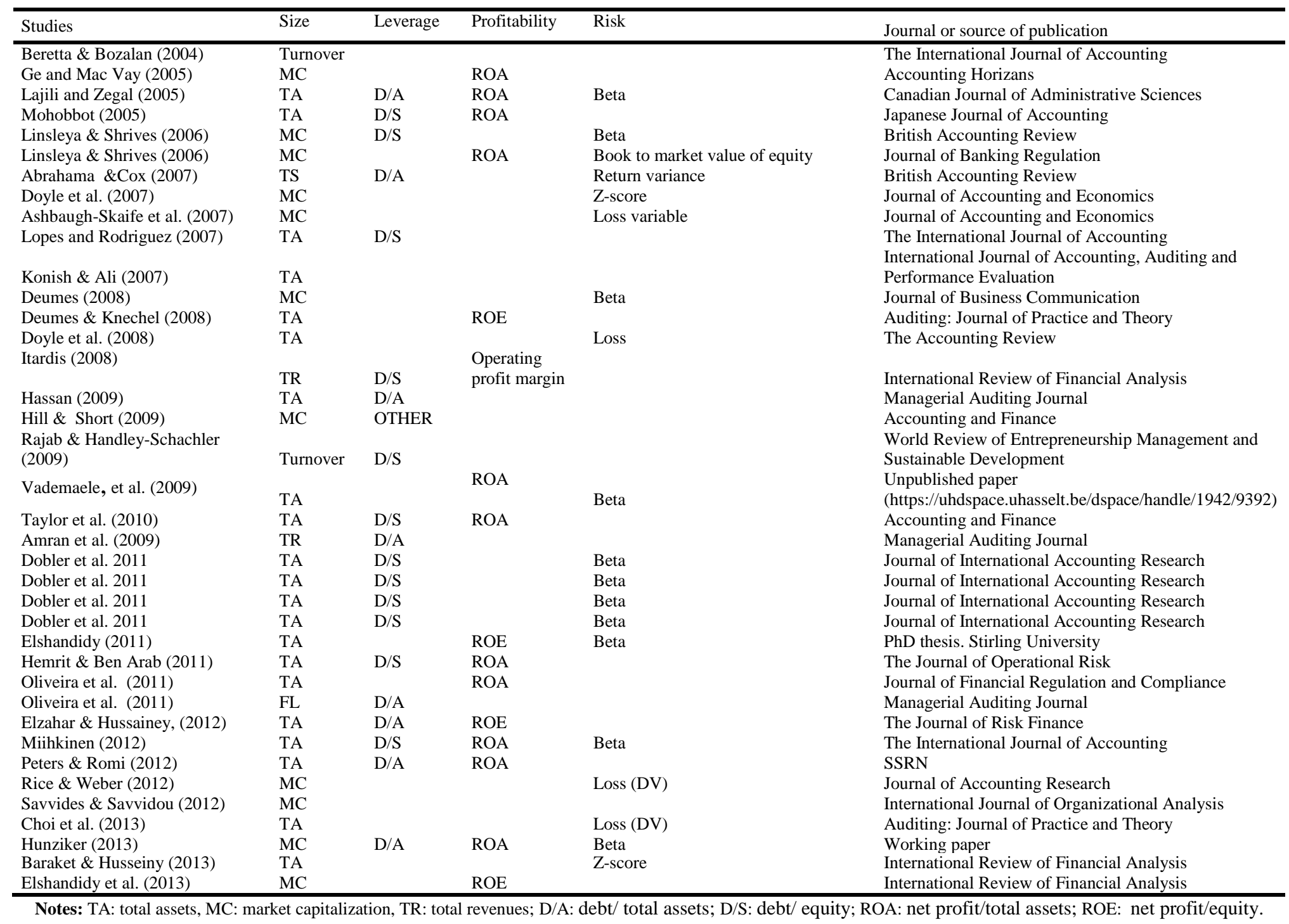


Table 3. Continued

\begin{tabular}{|c|c|c|c|c|c|}
\hline Studies & Size & Leverage & Profitability & Risk & Journal or source of publication \\
\hline Mokhtar and Mellett (2013) & $\overline{T R}$ & & & & Managerial Auditing Journal \\
\hline Ntim et al. (2013) & TA & $\mathrm{D} / \mathrm{A}$ & ROA & $\begin{array}{l}\text { Standard deviation of operational } \\
\text { profits }\end{array}$ & International Review of Financial Analysis \\
\hline Soodanian et al. (2013) & & $\mathrm{D} / \mathrm{A}$ & & & Research Journal of Finance and Accounting \\
\hline Uba Adamu (2013) & MC & & & Loss & $\begin{array}{l}\text { Journal of Applied Environmental and Biological } \\
\text { Sciences }\end{array}$ \\
\hline Al-Shammari (2014) & TA & $\mathrm{D} / \mathrm{A}$ & ROE & & Journal of Contemporary Issues in Business Research \\
\hline
\end{tabular}

Notes: TA: total assets, MC: market capitalization, TR: total revenues; D/A: debt/ total assets; D/S: debt/ equity; ROA: net profit/total assets; ROE: net profit/equity. 
Table 4. Corporate size, leverage ratio and risk reporting

\begin{tabular}{|c|c|c|c|c|c|c|c|c|c|c|}
\hline & $\begin{array}{l}\text { Sample } \\
\text { (N) }\end{array}$ & $\begin{array}{l}\text { Number } \\
\text { of studies } \\
\text { (K) }\end{array}$ & $\begin{array}{l}\text { Mean } \\
\text { correlation } \bar{r}\end{array}$ & $\begin{array}{l}\text { Observed } \\
\text { variance } S_{r}^{2}\end{array}$ & $\begin{array}{l}\text { Estimated error } \\
\text { variance } S_{e}^{2}\end{array}$ & $\begin{array}{l}\text { Percentage explained } \\
S_{e}^{2} / S_{r}^{2}\end{array}$ & Z-statitic & $95 \%$ confidence interval & $\chi_{K-1}^{2}$ & $\begin{array}{l}\text { File- } \\
\text { drawer }\end{array}$ \\
\hline \multicolumn{11}{|l|}{ Corporate size (A) } \\
\hline $\begin{array}{l}\text { Overall meta-analysis } \\
\text { Moderating factors }\end{array}$ & 26357 & 43 & $0.075^{* * *}$ & 0.036 & 0.001 & 4.480 & 2.615 & $0.018 ; 0.132$ & $959.758 * * *$ & 65 \\
\hline $\begin{array}{l}\text { Civil law } \\
\text { Common law }\end{array}$ & $\begin{array}{r}7139 \\
17897\end{array}$ & $\begin{array}{l}17 \\
20\end{array}$ & $\begin{array}{l}0.125 * * * \\
0.027\end{array}$ & $\begin{array}{l}0.027 \\
0.023\end{array}$ & $\begin{array}{l}0.002 \\
0.001\end{array}$ & $\begin{array}{l}8.400 \\
4.790\end{array}$ & $\begin{array}{l}3.113 \\
0.796\end{array}$ & $\begin{array}{l}0.046 ; 0.203 \\
-0.039 ; 0.094\end{array}$ & $\begin{array}{l}202.377 * * * \\
417.284 * * *\end{array}$ & $\begin{array}{l}31 \\
-\end{array}$ \\
\hline High uncertainty avoidance & 8372 & 17 & $0.146^{* * *}$ & 0.034 & 0.002 & 5.670 & 3.225 & $0.058 ; 0.234$ & $300.088 * * *$ & 39 \\
\hline Low uncertainty avoidance & 16973 & 18 & 0.005 & 0.012 & 0.001 & 8.420 & 0.214 & $-0.046 ; 0.057$ & $213.809 * * *$ & - \\
\hline $\begin{array}{l}\text { Voluntary } \\
\text { Mandatory }\end{array}$ & $\begin{array}{r}18046 \\
4881\end{array}$ & $\begin{array}{l}31 \\
12\end{array}$ & $\begin{array}{l}0.120 * * * \\
-0.016\end{array}$ & $\begin{array}{l}0.042 \\
0.015\end{array}$ & $\begin{array}{l}0.002 \\
0.002\end{array}$ & $\begin{array}{l}3.950 \\
16.320\end{array}$ & $\begin{array}{l}3.254 \\
-0.465\end{array}$ & $\begin{array}{l}0.047 ; 0.192 \\
-0.085 ; 0.052\end{array}$ & $\begin{array}{r}785.702 * * * \\
73.522 * * *\end{array}$ & 97 \\
\hline Excluding financial sector & 16643 & 27 & $0.123 * * *$ & 0.036 & 0.001 & 4.400 & 3.396 & $0.052 ; 0.195$ & $614.177 * * *$ & 95 \\
\hline $\begin{array}{l}\text { Financial sector } \\
\text { Mixed }\end{array}$ & $\begin{array}{r}592 \\
9122\end{array}$ & $\begin{array}{r}6 \\
10\end{array}$ & $\begin{array}{l}0.476 * * * \\
-0.037\end{array}$ & $\begin{array}{l}0.064 \\
0.007\end{array}$ & $\begin{array}{l}0.006 \\
0.001\end{array}$ & $\begin{array}{l}9.340 \\
15.570\end{array}$ & $\begin{array}{l}4.575 \\
-1.429\end{array}$ & $\begin{array}{l}0.272 ; 0.679 \\
-0.089 ; 0.014\end{array}$ & $\begin{array}{l}64.259 * * * \\
64.223 * * *\end{array}$ & $\begin{array}{l}11 \\
-\end{array}$ \\
\hline $\begin{array}{l}\text { TA } \\
\text { MC } \\
\text { TR } \\
\text { Turnover }\end{array}$ & $\begin{array}{r}14064 \\
11513 \\
458 \\
241 \\
\end{array}$ & $\begin{array}{r}24 \\
12 \\
4 \\
2 \\
\end{array}$ & $\begin{array}{l}0.111 * * * \\
-0.011 \\
0.242 * * * \\
0.283\end{array}$ & $\begin{array}{l}0.037 \\
0.007 \\
0.043 \\
0.073 \\
\end{array}$ & $\begin{array}{l}0.001 \\
0.001 \\
0.007 \\
0.007 \\
\end{array}$ & $\begin{array}{l}4.420 \\
14.790 \\
17.880 \\
9.590 \\
\end{array}$ & $\begin{array}{l}2.805 \\
-0.461 \\
2.328 \\
1.483 \\
\end{array}$ & $\begin{array}{l}0.033 ; 0.188 \\
-0.058 ; 0.036 \\
0.038 ; 0.446 \\
-0.091 ; 0.658\end{array}$ & $\begin{array}{r}543.290^{* * *} * \\
81.131^{* * *} \\
22.367 * * * \\
20.845^{* * *}\end{array}$ & $\begin{array}{l}65 \\
- \\
6 \\
- \\
\end{array}$ \\
\hline \multicolumn{11}{|l|}{ Leverage (B) } \\
\hline $\begin{array}{l}\text { Overall meta-analysis } \\
\text { Moderating factors }\end{array}$ & 4920 & 25 & $0.067^{* * *}$ & 0.027 & 0.005 & 18.170 & 2.034 & $0.002 ; 0.132$ & $137.584 * * *$ & 9 \\
\hline Civil law & 1251 & 9 & $0.109^{* *}$ & 0.027 & 0.007 & 25.750 & 1.993 & $0.001 ; 0.217$ & $32.945 * * *$ & 4 \\
\hline Common law & 3669 & 16 & 0.053 & 0.027 & 0.004 & 16.030 & 1.299 & $-0.037 ; 0.134$ & $99.830^{* * * *}$ & - \\
\hline High uncertainty avoidance & 1675 & 11 & 0.061 & 0.027 & 0.004 & 14.850 & 1.231 & $-0.036 ; 0.115$ & $46.389 * * *$ & - \\
\hline Low uncertainty avoidance & 3116 & 13 & 0.064 & 0.028 & 0.004 & 14.850 & 1.390 & _0.026; 0.155 & $87.557 * * *$ & - \\
\hline Voluntary & 4455 & 18 & $0.073^{* *}$ & 0.025 & 0.004 & 16.650 & 2.150 & $0.006 ; 0.148$ & $114.084 * * *$ & 11 \\
\hline Mandatory & 465 & 7 & -0.012 & 0.059 & 0.015 & 25.190 & -0.135 & $-0.168 ; 0.193$ & $27.788 * * *$ & - \\
\hline Excluding financial sector & 4055 & 20 & $0.082 * * *$ & 0.026 & 0.005 & 18.620 & 2.278 & $0.011 ; 0.159$ & $107.453 * * *$ & 13 \\
\hline Mixed & 736 & 4 & -0.041 & 0.024 & 0.005 & 22.900 & -0.534 & $-0.191 ; 0.109$ & $17.467 * * *$ & - \\
\hline $\mathrm{D} / \mathrm{S}$ & 2120 & 15 & $0.170 * * *$ & 0.034 & 0.007 & 19.410 & 3.556 & $0.076 ; 0.264$ & $77.288 * * *$ & 17 \\
\hline $\mathrm{D} / \mathrm{V}$ & 2380 & 9 & 0.014 & 0.006 & 0.004 & 60.380 & 0.551 & $-0.037 ; 0.066$ & $14.904 * * *$ & - \\
\hline
\end{tabular}


Table 5. Profitability, corporate risk and risk reporting

\begin{tabular}{|c|c|c|c|c|c|c|c|c|c|c|}
\hline & $\begin{array}{l}\text { Sample } \\
\text { (N) }\end{array}$ & $\begin{array}{l}\text { Number } \\
\text { of studies } \\
\text { (K) }\end{array}$ & $\begin{array}{l}\text { Mean } \\
\text { correlation } \bar{r}\end{array}$ & $\begin{array}{l}\text { Observed } \\
\text { variance } S_{r}^{2}\end{array}$ & $\begin{array}{l}\text { Estimated error } \\
\text { variance } S_{e}^{2}\end{array}$ & $\begin{array}{l}\text { Percentage explained } \\
S_{e}^{2} / S_{r}^{2}\end{array}$ & Z-statitic & $95 \%$ confidence interval & $\chi_{K-1}^{2}$ & $\begin{array}{l}\text { File- } \\
\text { drawer }\end{array}$ \\
\hline \multicolumn{11}{|l|}{ Profitability $(\mathrm{C})$} \\
\hline $\begin{array}{l}\text { Overall meta-analysis } \\
\text { Moderating factors }\end{array}$ & 5834 & 19 & $0.044^{* * *}$ & 0.009 & 0.003 & 34.510 & 2.006 & $0.001 ; 0.088$ & $55.051 * * *$ & 5 \\
\hline $\begin{array}{l}\text { Civil law } \\
\text { Common law }\end{array}$ & $\begin{array}{l}1240 \\
4161\end{array}$ & $\begin{array}{l}8 \\
9\end{array}$ & $\begin{array}{l}0.036 \\
0.039\end{array}$ & $\begin{array}{l}0.011 \\
0.009\end{array}$ & $\begin{array}{l}0.006 \\
0.002\end{array}$ & $\begin{array}{l}56.210 \\
23.830\end{array}$ & $\begin{array}{l}0.956 \\
1.238\end{array}$ & $\begin{array}{l}-0.037 ; 0.110 \\
-0.022 ; 0.104\end{array}$ & $\begin{array}{l}14.232 * * * \\
37.762 * * *\end{array}$ & - \\
\hline High uncertainty avoidance & 1536 & 8 & $0.104^{* *}$ & 0.022 & 0.005 & 23.100 & 1.988 & $0.001 ; 0.207$ & $34.633 * * *$ & 4 \\
\hline Low uncertainty avoidance & 3737 & 8 & 0.009 & 0.002 & 0.002 & 93.280 & 0.585 & $-0.023 ; 0.043$ & 8.576 & - \\
\hline $\begin{array}{l}\text { Voluntary } \\
\text { Mandatory } \\
\text { Excluding financial sector } \\
\text { Financial sector }\end{array}$ & $\begin{array}{r}5289 \\
545 \\
5079 \\
261\end{array}$ & $\begin{array}{r}15 \\
4 \\
13 \\
2\end{array}$ & $\begin{array}{l}0.043 \\
0.059 \\
0.056^{* *} \\
-0.040^{* * *}\end{array}$ & $\begin{array}{l}0.009 \\
0.009 \\
0.009 \\
0.000\end{array}$ & $\begin{array}{l}0.003 \\
0.007 \\
0.002 \\
0.007\end{array}$ & $\begin{array}{l}31.510 \\
79.430 \\
27.130 \\
100.000\end{array}$ & $\begin{array}{l}1.721 \\
1.246 \\
2.075 \\
-10.087\end{array}$ & $\begin{array}{l}-0.006 ; 0.092 \\
-0.034 ; 0.153 \\
0.003 ; 0.108 \\
-0.047 ;-0.032\end{array}$ & $\begin{array}{l}49.880^{* * * *} \\
5.035 \\
47.923^{* * *} \\
0.008\end{array}$ & $\overline{5}$ \\
\hline Mixed & 266 & 4 & -0.006 & 0.008 & 0.015 & 100.000 & -0.151 & $-0.094 ;-0.080$ & 2.133 & - \\
\hline $\begin{array}{l}\text { ROE } \\
\text { ROA } \\
\end{array}$ & $\begin{array}{l}2682 \\
3318 \\
\end{array}$ & $\begin{array}{r}5 \\
13 \\
\end{array}$ & $\begin{array}{l}0.004 \\
0.056^{*} \\
\end{array}$ & $\begin{array}{l}0.000 \\
0.014 \\
\end{array}$ & $\begin{array}{l}0.002 \\
0.004 \\
\end{array}$ & $\begin{array}{l}100.000 \\
28.590 \\
\end{array}$ & $\begin{array}{l}0.452 \\
1.742 \\
\end{array}$ & $\begin{array}{l}-0.015 ; 0.024 \\
-0.007 ; 0.119 \\
\end{array}$ & $\begin{array}{r}1.383 \\
45.466^{* * * *} \\
\end{array}$ & - \\
\hline \multicolumn{11}{|l|}{ Risk factor (D) } \\
\hline $\begin{array}{l}\text { Overall meta-analysis } \\
\text { Moderating factors }\end{array}$ & 17222 & 20 & $0.054 * * *$ & 0.004 & 0.001 & 28.500 & 3.825 & $0.026 ; 0.082$ & $70.147 * * *$ & 16 \\
\hline Civil law & 5784 & 5 & $0.043 * *$ & 0.003 & 0.001 & 38.990 & 2.065 & $0.002 ; 0.084$ & $15.390 * * *$ & 3 \\
\hline Common law & 10207 & 10 & $0.053^{* * *}$ & 0.003 & 0.001 & 31.280 & 3.009 & $0.018 ; 0.087$ & $31.966^{* * * *}$ & 12 \\
\hline High uncertainty avoidance & 6465 & 8 & $0.065^{* *}$ & 0.007 & 0.001 & 16.940 & 2.179 & $0.006 ; 0.124$ & $47.212 * * *$ & 10 \\
\hline Low uncertainty avoidance & 9707 & 9 & $0.045^{* * *}$ & 0.002 & 0.001 & 47.750 & 3.065 & $0.016 ; 0.073$ & $18.921 * * *$ & 3 \\
\hline Voluntary & 12886 & 13 & $0.059 * * *$ & 0.004 & 0.001 & 21.660 & 3.155 & $0.022 ; 0.096$ & $60.005 * * *$ & 19 \\
\hline Mandatory & 4336 & 7 & $0.039 * *$ & 0.002 & 0.001 & 78.790 & 2.302 & $0.006 ; 0.072$ & $8 . .884$ & 1 \\
\hline Excluding financial sector & 12295 & 14 & $0.055^{* * *}$ & 0.004 & 0.001 & 27.220 & 3.237 & $0.022 ; 0.089$ & $51.423^{* * *}$ & 15 \\
\hline Financial & 262 & 2 & 0.101 & 0.007 & 0.007 & 100.000 & 1.741 & $-0.012 ; 0.216$ & 1.831 & - \\
\hline Mixed & 4665 & 4 & 0.048 & 0.003 & 0.001 & 24.770 & 1.643 & $-0.009 ; 0.105$ & $16.146^{* * *}$ & 2 \\
\hline Beta & 1597 & 11 & $0.081 * *$ & 0.010 & 0.007 & 64.113 & 2.256 & $0.010 ; 0.153$ & $17.153^{* * *}$ & 6 \\
\hline Standard deviation of return & 571 & 2 & $0.229 * * *$ & 0.002 & 0.003 & 100.000 & 6.339 & $0.158 ; 0.300$ & 1.664 & 4 \\
\hline Loss and Z-score & 15035 & 6 & $0.045^{* * *}$ & 0.002 & 0.000 & 19.790 & 2.468 & $0.009 ; 0.081$ & $30.324 * * *$ & 5 \\
\hline
\end{tabular}

Notes: Notes: Dependent variable: risk disclosure; ROA: net profit/total assets; ROE: net profit/equity. $* \mathrm{p}<.10 ; * * \mathrm{p}<.05 ; * * * \mathrm{p}<.01$. 